本ニュースレターにおいては下記の記事を募集しております。皆様のご応募をお待ちしております。読者としては最新情報の入手，

執筆者としては情報発信の良き場として活用ください。下記のページでも閲覧することができます。

http://www2.iee.or.jp/ver2/ias/nl/nl2.cgi

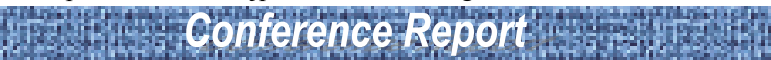

学界情報 国際会議レポート

国際会議レポートでは,「読んで楽しい記事, 読者が次回に行きたくなるような 記事, 参加者の生の声を反映した記事」をテーマに, A4 原稿 1 ページの記事を募 集しております。論文提出時の苦労話から懇親会での四方山話まで幅広い内容に対 応いたしますので,ぜひチャレンジしてください。

\section{Industry Applications Forum Report}

\section{産業応用フォーラム報告（基本的に奇数月）}

産業店用フォーラム報告では, 開催実施された産業応用フォーラムの講演内容や フォーラム会場の様子に関する記事を掲載いたします。フォーラムの参加募集記事 には掲載されなかった具体的な講演内容や会場の様子を, 参加できなかった会員の 皆様へのご報告として, また, そのフォーラムの次回開催に興味をもっていただけ

るような情報提供の場としてご紹介させていただきます。

募集対象 : 教育機関 (大学及び高専)，および公的機関 (国または地方自治体の所属機関)，企業の研究・開発機関であり，原則として 電気学会会員であることを条件といたします。

応募方法 : 電子メールにて, 下記送付先に数行程度の紹介文を送付してください。

送付先 (記事募集共通アドレス)：iaedit (at) ieej.org

掲載可否：産業応用部門編修広報委員会で審議の上，掲載の可否を連絡します。また，「国際会議レポート」「研究グループ紹介」 「産業応用フォーラム報告」「技術開発レポート」の掲載原稿の著作権は学会に帰属し，文責は投稿者が負うものとします。

募集期間 : 国際会議レポートは国際会議開催前または開催後 1 カ月まで，それ以外は随時受付いたします。

\section{Rosearah Grous Introduction}

研究グループ紹介（基本的に偶数月掲載）

研究グループ紹介では, 国内外の教育機関 (大学および高専) および公的機関 (国 または地方自治体の所属機関）におおる活動状況を隔月 A4 原稿 1 ページで掲載し ております。研究内容に限らず，研究室の雾囲気や学生の様子など，ぜひ貴研究室 をご紹介させてください!

\section{技術開発レポート（基本的に偶数月）}

技術開発レポートでは，各機閏などに㧍ける最新の研究開発成果について，研究 分野全体の動向や今後の展望，技術開発の裏話などを交えながら，分かりや寸く隔 月 A4 原稿 1 ページでご紹介しています。論文とは一味違った情報発信の場として

\section{Techrical Development Report}

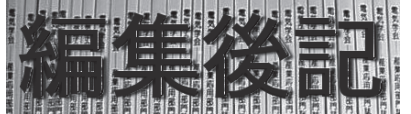

月日の経つのはとても早い もので，今年も残り 2 か月と なりました。皆様いかがお過 ごしでしょうか。寒さが段々と㛜しくなってくる時期ですの で，どうぞお体にはお気を付けください。

2019 年は「令和」への改元, 消費税増税など, 生活に直接 関わる大きな出来事がありました。皆様の生活にも何か変化 はありましたでしょうか。日本では普及が進んでいないとい われる「決済のキャッシュレス化」ですが, 消費税増税に伴 い国を挙げて推進しているようです。私自身もキャッシュレ ス化の波には乗り遅れておりまして, 数多くあるサービスか らどれを利用するべきか困惑しているところです。

さて, 今月号の巻頭言は, 産業応用部門和文論文誌編修長 の星先生（東京理科大学）にご執筆いただきました。魅力的 な論文誌とはどのようなものか, 読者目線, 投稿者目線の両 視点からご説明いただいております。また，電子投稿・査読 システムについて, その重要性と現在の課題について述べら れております。本記事中には論文委員会委員への適任者推薦 のお願いもございますので，会員の皆様には是非ともご一読 いただき，査読システム登録データの有効活用に向けご協力 いただきたく存じます。 